\section{RICYDE. Revista Internacional de Ciencias del Deporte doi: $10.5232 /$ ricyde \\ Rev. Int. cienc. deporte}

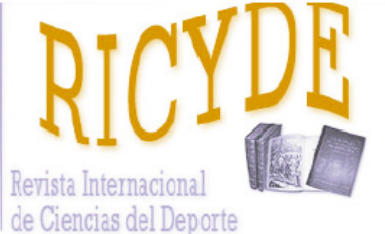

RICYDE. Revista Internacional de Ciencias del Deporte Volume XV - Year XV

Pages: 209-224 - ISSN: 1885-3137 Issue 56 - April 2019

\title{
Teaching Games for Understanding in basketball camp: the impact on process and product performance \\ Teaching Games for Understanding en un campamento de baloncesto: impacto en el rendimiento del proceso y del producto
}

\section{Mariana Calábria-Lopes ${ }^{1}$, Pablo Juan Greco², Juan Carlos Pérez-Morales²}

1. Universidade Federal de Viçosa. Brazil

2. Universidade Federal de Minas Gerais. Brazil

\begin{abstract}
The purposes of the current study were to verify the correlation between product and process performance of basketball passing and shooting skills and to examine the effects of TGfU intervention in a basketball camp format on process and product performance of these skills in children. Participants included 18 novices (age: $M=10.89$, $\mathrm{SD}=1.02$ years old) in basketball. They participated in 22.5 hours of TGfU training over five consecutive days and completed pre and post assessments. Data were collected using process and product assessments, and a declarative knowledge questionnaire. Results showed no correlation between the dependent variables. Significant differences between pre- and posttest were found only for process performance of passes, product performance of shooting in game context, and declarative knowledge of both skills. No differences were found for product-oriented assessment of shooting and passing isolated skills. Therefore, it was possible to conclude that the use of process and product assessments to evaluate sport-specific skills after a TGfU intervention in a basketball camp may provide different and complementary information about performance levels in teaching - learning process.
\end{abstract}

Key words: TGfU; basketball camp; process- and product-oriented skill assessment; children.

\section{Resumen}

En este trabajo se verificaron a) la correlación entre el rendimiento del producto y el proceso del pase y lanzamiento en baloncesto, b) los efectos en el rendimiento del proceso y producto de estas habilidades. Se aplicó un proceso de intervención con base en los principios de la enseñanza por la comprensión - TGfU - en un campamento de baloncesto. Participaron del entrenamiento 18 niños (edad: $M=10.89, S D=1.02$ años) novatos en baloncesto. El programa tuvo una duración de 22.5 horas en cinco días consecutivos con diseño de pre y pos test. Se evaluó el proceso y el producto del pase y lanzamiento de forma aislada y en situación de juego de 3 vs. 3. Se aplicó también un cuestionario de conocimiento táctico declarativo. Los resultados no mostraron correlación entre las variables dependientes de pase y lanzamiento (producto y proceso), y conocimiento declarativo. Se encontraron diferencias significativas entre el pre y el pos test solo para el proceso en el pase y el producto en el lanzamiento en contexto de juego y conocimiento declarativo de las habilidades de lanzamiento y pase. No se encontraron diferencias para la evaluación orientada al producto en las habilidades aisladas de lanzamiento y pase. Se concluye que el uso de evaluaciones tanto del proceso cuánto del producto para habilidades específicas, después de un programa de intervención como el TGfU en un campamento de baloncesto, puede proporcionar informaciones diferentes y complementarias sobre los niveles de rendimiento en procesos de enseñanza - aprendizaje.

Palabras clave: TGfU; campamento de baloncesto; evaluación orientada al proceso y producto; niños.

Correspondence/correspondencia: Juan Carlos Pérez Morales

Universidade Federal de Minas. BIrasil

Email: jkperezmorales@gmail.com 
Calábria-Lopes, M.; Greco, P. J. \& Pérez-Morales, J. C. (2019). Teaching Games for Understanding in basketball camp: the impact on process and product performance. RICYDE. Revista internacional de ciencias del deporte. 56(15), 209-224.

\section{Introduction}

$\mathrm{T}$ he use game-centered approaches for teaching team sports in schools and sport clubs has grown in last years, given the criticism to the traditional technique-based approaches (Araujo, Mesquita, Hastie and Pereira, 2015; Raab, 2007). The game-centered approaches aim to develop learners cognitive processing capacities, that is his or her understanding of game logic (Gutierrez, 2016).

The Teaching Games for Understanding (TGfU) is probably the most influential game-centered model (Memmert et al., 2015). The TGfU model was first presented by Bunker and Thorpe (1982) and is based on making students think about the tactical problems presented in gamelike situations and answering questions designed to develop tactical awareness (Griffin and Patton, 2005). Increases in tactical awareness may improve decision-making about skill selection (what to do) and skill execution (how to do it), combining tactical and technical components (Kirk and MacPhail, 2002).

This work will focus on TGfU technical component, which is mostly taught in an explicit way (Raab, 2007). This means that performance improvements are accompanied by the ability to verbally communicate rules of movement execution (Maxwell, Capio and Masters, 2017). Although it has been shown that explicit motor learning is more reliant on the available working memory resources and more likely to be hindered by secondary tasks (Masters, Poolton and Maxwell, 2008; Maxwell, Masters and Eves, 2003), the TGfU approach has some benefits. One advantage on skill development is that the process occurs in a realistic and enjoyable context, which may increase sport motivation and participation (Strean and Holt, 2000). In addition, skill development progresses at a pace that is manageable for the learners (Pill, 2006).

The skill development progress in invasion games (e.g., basketball, soccer) is often assessed using the Game Performance Assessment Instrument - GPAI (Memmert et al., 2015). One of the seven components of GPAI associated with effective game performance is the Skill Execution Index (SEI), which measures the (non-) efficient execution of selected skills in a game-like task. The GPAI can be considered a product-oriented assessment (i.e., measures the learning outcome), which is based on a quantitative score (e.g., how accurate a pass was or how many baskets a team scored) that results from the dynamic execution of the skill (Donelly, Mueller and Gallahue, 2017). Product-oriented assessments are quick and easy to assess and interpret, but they do not provide information about how the outcomes were achieved (Hulteen et al., 2015). A process-oriented assessment describes qualitative movement patterns (Logan, Robinson and Getchell, 2011), and may be advantageous for accurately identifying impaired skill components (Capio, Sit and Abernethy, 2011), preventing injuries (Nicholls, Fleisig, Elliot, Lyman and Osinski, 2003), and increasing learners' feeling of competence (Hulteen et al., 2015).

Previous studies presented low-to-moderate relationships between process and product assessments indicating that a single evaluation may not provide a full understanding of motor skill development (Logan et al., 2011; Rudd et al., 2016; Stodden et al., 2008). For example, the developmental sequences of the throwing skill predict $69-85 \%$ of ball speed in children aged 6-13 years (Roberton and Konczak, 2001) and are strong predictors of kinematic and temporal variables and ball velocity in children between 3 and 15 years old (Stodden, Langendorfer, Fleisig and Andrews, 2006b; Stodden, Langendorfer, Fleisig and Andrews, 2006a). It is important to highlight that most of this evidence was provided by studies that focused on isolated fundamental movement skills performed in closed environments and, therefore, do not assess the complex series of skills involved in games. 
Calábria-Lopes, M.; Greco, P. J. \& Pérez-Morales, J. C. (2019). Teaching Games for Understanding in basketball camp: the impact on process and product performance. RICYDE. Revista internacional de ciencias del deporte. 56(15), 209-224.

Furthermore, it should be noted that much of the research about game-centered approaches, has focused on the cognition and thought processes (Koekoek and Knoppers, 2015; Mesquita, Farias and Hastie, 2012). The few studies on TGfU that aimed to investigate skill acquisition have attempted to compare the TGfU approach to other approaches (i.e., technical instruction) to show the benefits of one over another (French, Werner, Rink, Taylor and Hussey, 1996a, French, Werner, Taylor, Hussey and Jones, 1996b; Rink, French and Tjeerdsma, 1996; Turner and Martinek, 1999). However, scientists argue that the main issue does not relate to supremacy of any teaching approaches, but to 'what' we teach and how we can integrate technical skills to game play to develop students' 'understanding' of the game and allow them to become successful game players (Metzler, 2011). Therefore, recent studies on soccer (Harvey, Cushion, Wegis and Massa-Gonzalez, 2010; Pizarro, Domínguez, Serrano, García-González and Del Villar, 2017), hockey (Nathan, 2015), and sailing (Morales-Belando and Arias Estero, 2017) have been carried out to investigate the effects of the TGfU model only. These studies revealed significant changes between baseline and post-intervention measures for the overall skill execution. A game-based environment should not be misread as omitting or deemphasizing the importance of correct technique (Crespo, Reid and Miley, 2004), especially in team sports, where ball skills are assumed to be complex and performed in a decision-making environment (Corrêa, Vilar, Davids and Renshaw, 2014).

Moreover, the effectiveness of the TGfU program on tactical and technical components was found in studies (for a review see Stolz and Pill, 2014) with more than three week of intervention (about 16 hours of lessons). In the current study, the learning phase is presented as a "basketball camp". Camps may be one of the largest organized interventions for children in the United States (Bialeschki, Henderson and James, 2007) and is a European trend in youth sport (De Knop, 1996). Generally, sport camps occur over one week or more days and the children stay the whole day ("general day" - approximately 5-6 hours) or overnight (i.e., Anderson-Butcher, Iachini, Riley, Wade-Mdivanian, Davis and Amorose, 2013; Smith, Ullrich-French, Walker II and Hurley, 2006). Sport camps have positive effects on multiple aspects of children's development, like in cognitive, social (Salazar, Juárez-Lozano, AndradeSánchez, Peña-Vargas, Arrellano-Ceballos and Hernández, 2016), behavioral (e.g. self-steem, friendship skills, leadership) and academic aspects (Riley and Anderson-Butcher, 2012). More specifically, sport camps are a regular way of training children (LeMar and Deutsch, 2015) and a great opportunity for them to develop and mastery sports (Thurber, Scanlin, Scheuler, and Henderson, 2007) and fundamental skills (Zwicker, Rehal, Sodhi, Karkling, Paul, Hilliard and Jarus, 2015). Last but not least, sport camps provide ample opportunities for youth to be active and they can be an adequate environment to investigate and implement sport teaching models (Wahl-Alexander and Morehead, 2017). Despite the growing popularity of sport camps and their importance to practice and learn sport, there is no past evidence investigating the effect of TGfU in this setting.

Considering the above mentioned issues, the first purpose of this study is to investigate the relationship between process and product assessment scores for passing and shooting basketball skills. The second aim is to investigate the effects of the TGfU approach with 22.5 hours of training distributed in five consecutive days, in a format of a sport camp, on shooting and passing basketball skills in novices measured through both product and process-oriented assessments. 
Calábria-Lopes, M.; Greco, P. J. \& Pérez-Morales, J. C. (2019). Teaching Games for Understanding in basketball camp: the impact on process and product performance. RICYDE. Revista internacional de ciencias del deporte. 56(15), 209-224.

https://doi.org/10.5232/ricyde2019.05606

\section{Methods}

\section{Participants}

Twenty children were recruited to participate in the study through notice boards and flyers distributed at schools and sports clubs in Germany. All of them were novices in basketball and had no previous experience but the physical education classes at school. The exclusion criteria was to attend less than $75 \%$ of the intervention sessions. Therefore, only eighteen participants (66.7\% boys), aged between 9 and 12 years $\left(M_{a g e}=10.89\right.$ years, $S D=1.02$ years) were included in the analysis. Other studies have shown that children that age already take part in sport camps (Anderson-Butcher et al., 2013), including basketball camps (Smith et al., 2006). Participants assent was obtained with parental/guardian consent. The study was approved by the local Institutional Review Board.

\section{Procedures}

This study followed a pre- and post-intervention design. The intervention consisted of teaching passing and shooting skills in basketball, using the TGfU model.

\section{Coaches training in TGfU}

Two basketball coaches were recruited and trained in the TGfU approach prior to the study (i.e., 10-hour training). The training program was conducted over a two-week period and consisted of three main modules: 1) introduction to the TGfU approach and its basic principles 2) emphasis on the use of modified games and questioning for the formation of young basketball players through videos and book chapters (Mitchell, Oslin and Griffin, 2006); 3) a pilot session conducted by both trainers. A researcher experienced in the TGfU model, was present at all trainings modules and practice sessions and clarified any issues. At the end, the coaches received the nine TGfU session plans, including the questions that were going to be asked.

\section{Design of the interventions sessions}

The training sessions were adapted from the book Teaching Sport Concepts and Skills (Mitchell et al., 2006) and included the tactical level of complexity I and II in basketball. The sessions contained the following main segments: (a) "game form", with a tactical problem to develop game appreciation; (b) "tactical awareness", which allows children to work out their own performance solutions through focused questioning. The questioning was carried out twice during each task - once after the first game form to guide them in the task and then at the end of the session to consolidate these concepts. (c) "skill execution" to develop the technical skills of chest pass, dribbling, and shooting with a step-by-step method in which the movement rules outlined by Schroeder and Bauer (2001) were adapted and read by the coaches before and after the technical training and at the end of the session (Table 1); (d) return to "game form" for reinforcing the tactical problem and the skill practiced. 
Calábria-Lopes, M.; Greco, P. J. \& Pérez-Morales, J. C. (2019). Teaching Games for Understanding in basketball camp: the impact on process and product performance. RICYDE. Revista internacional de ciencias del deporte. 56(15), 209-224.

https://doi.org/10.5232/ricyde2019.05606

Table 1: Instructions for Basketball Shooting and Chest Passing Skills

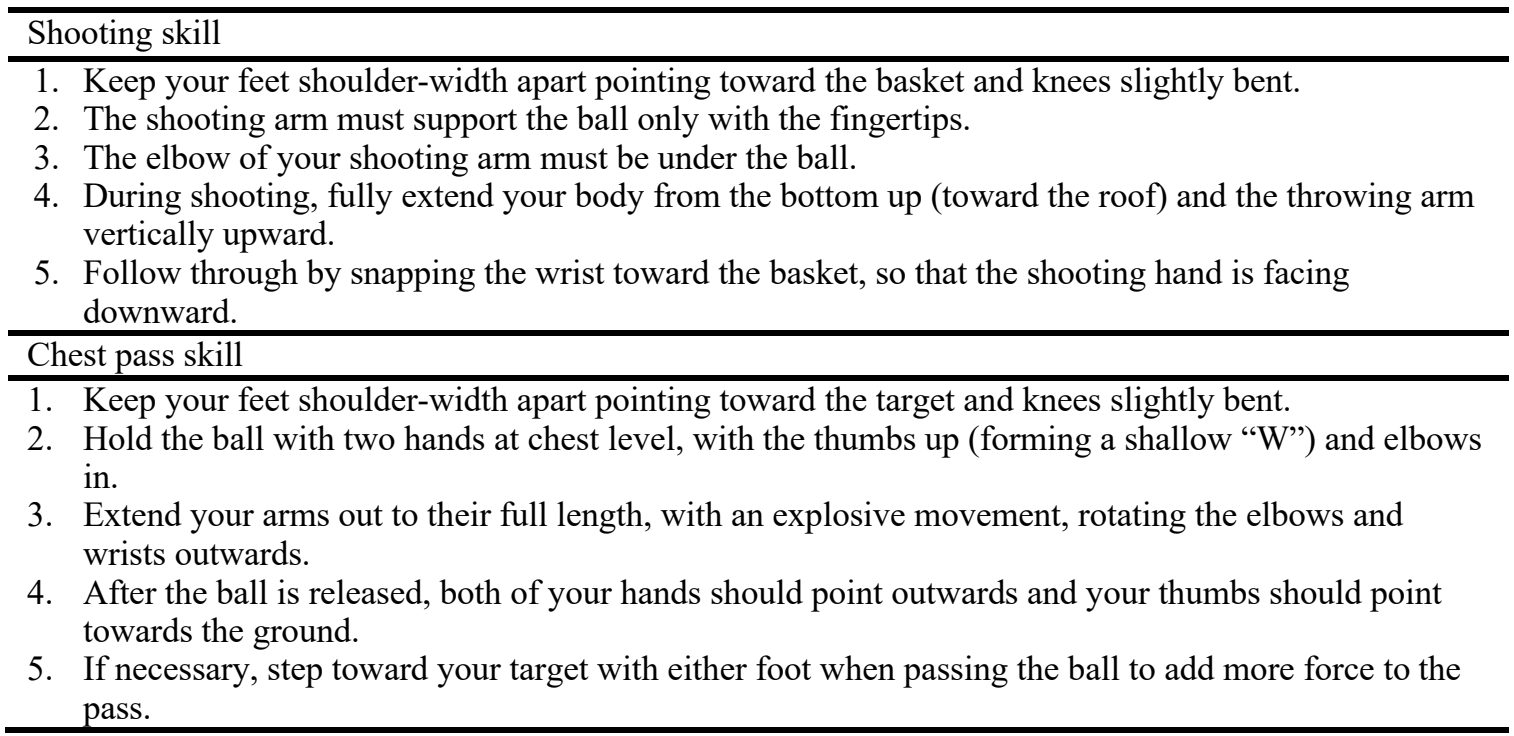

The intervention sessions took place over five consecutive days, during a school holiday, with five hours of training per day (except on the first day). A total of nine 2.5 hours sessions were performed in this phase, one session on the first day and two sessions on each of the four remaining days. In each session, one tactical problem and one technical skill were taught. The shooting and chest pass skills were the main focus of three different sessions each (Table 2). The learning phase lasted 22.5 hours, much more than in other standard laboratory testing and interventions studies with the TGfU approach (Harvey et al., 2010; Morales-Belando and AriasEstero, 2017; Nathan, 2015; Pizarro et al., 2017).

Table 2: Training Schedule and Sessions Contents

\begin{tabular}{|c|c|c|}
\hline Session & Tactical problem and skill practiced & Session focus \\
\hline 1 & $\begin{array}{l}\text { Attacking the basket } \\
\text { Skill: Shooting }\end{array}$ & Shooting within the zone \\
\hline 2 & $\begin{array}{l}\text { Maintaining ball possession } \\
\text { Skill: Passing }\end{array}$ & $\begin{array}{l}\text { Creating passing lanes by using on ball and } \\
\text { off ball movements }\end{array}$ \\
\hline 3 & $\begin{array}{l}\text { Maintaining ball possession } \\
\text { Skill: Dribbling }\end{array}$ & Creating passing lanes while playing off ball \\
\hline 4 & $\begin{array}{l}\text { Maintaining ball possession } \\
\text { Skill: Passing }\end{array}$ & Decision-making before passing \\
\hline 5 & $\begin{array}{l}\text { Attacking the basket } \\
\text { Skill: Shooting }\end{array}$ & $\begin{array}{l}\text { Identifying an open lane to the basket and } \\
\text { dribbling to drive and shoot }\end{array}$ \\
\hline 6 & $\begin{array}{l}\text { Using space in attack } \\
\text { Skill: Dribbling }\end{array}$ & $\begin{array}{l}\text { Use the dribble for repositioning to make a } \\
\text { pass }\end{array}$ \\
\hline 7 & $\begin{array}{l}\text { Creating space to attack } \\
\text { Skill: Passing }\end{array}$ & Creating passing lanes in the zone using cuts \\
\hline 8 & $\begin{array}{l}\text { Attacking the basket } \\
\text { Skill: Shooting }\end{array}$ & Using given-and-go to score \\
\hline 9 & $\begin{array}{l}\text { Creating space to attack } \\
\text { Skill: Dribbling }\end{array}$ & Setting a pick to create space \\
\hline
\end{tabular}

In each session, approximately 30 minutes were spent practicing the technique and approximately two hours were spent performing tactical tasks (i.e., 3 on 3 and 5 on 5 games, and small games), which also required the execution of the technical movements. Although the small games (i.e., hand games from the Ballschool concept - Kröger and Roth, 2005) have the same tactical problem as the focus of the session, they were included in the schedule more for fun and to motivate the children through diversity (not only 3 vs. 3 and with the aim to do a 
Calábria-Lopes, M.; Greco, P. J. \& Pérez-Morales, J. C. (2019). Teaching Games for Understanding in basketball camp: the impact on process and product performance. RICYDE. Revista internacional de ciencias del deporte. 56(15), 209-224.

https://doi.org/10.5232/ricyde2019.05606

basket). The time for each activity was controlled. An example of a session is depicted in Table 3.

Table 3. Example of a Training Schedule of One Session

\begin{tabular}{cc}
\hline Time & Activity \\
\hline $20 \mathrm{~min}$ & Warm-up activity + stretching \\
$20 \mathrm{~min}$ & 3 on 3 game (tactical problem) \\
$30 \mathrm{~min}$ & Technical training (passing, dribbling or shooting) \\
$20 \mathrm{~min}$ & Small game \\
$20 \mathrm{~min}$ & 3 on 3 game (same tactical problem) \\
$20 \mathrm{~min}$ & 5 on 5 game \\
$20 \mathrm{~min}$ & Pause (water break, explanations, etc.) \\
\hline
\end{tabular}

\section{Data collection}

\section{Verifying the treatment}

To ensure that the model was correctly applied, the training sessions were supervised by a researcher with experience in sports teaching methodology. The researcher also attended the training sessions and confirmed that the coaches implemented the sessions according to the intervention plan.

\section{Test Phase}

Participants completed the pre- and post-intervention assessments designed to measure the effect of the TGfU approach. Both assessments consisted of identical experimental procedures and conditions (e.g., period of the day, balls, etc.) and the tests were counterbalanced across each condition. Four different tests were applied: (a) product performance of isolated basketball shooting and chest pass skills, (b) basketball shooting and passing performance in game conditions, (c) process performance of basketball shooting and chest pass skills, and (d) declarative knowledge. Data from dribbling skill could not be used in this study due to technical problems to assess the dribbling speed (i.e., photocells).

To ensure the reliability of the assessments (i.e., b, c and d), two independent raters (national C-license basketball trainers) with more than five years of experience in coaching basketball were trained for 10 hours in each instrument, viewing and analyzing video clips $(b, c)$ and sheets with movement rules (d).

All skill tests occurred on a official basketball court according to FIBA rules. The balls were smaller and lighter than adults' (Molten N. 5) to facilitate ball handling and provide more enjoyable experiences for the children (Arias, Argudo and Alonso, 2012).

(a) Product performance of isolated basketball shooting and passing skills - In the basketball shooting test, participants were required to throw the ball into the basket without jumping from a distance of $2.80 \mathrm{~m}$ from the projected line of the backboard (Showalter, 2007). Participants performed two blocks of 10 trials and shooting performance was assessed accordingly (Lam, Maxwell and Masters, 2009). In order to assess the product performance of the chest pass skill, we adapted the Heidelberger Basketball tests (HBT - Bos, 1988) and the Poolton, Masters and Maxwell (2007) pass test. Participants were told to pick the basketball with two hands, throw the ball as fast as possible in the center of the target, and catch it again without bouncing. The target was marked on the wall of the sport facility and was comprised of three concentric squares with 30, 60 and $90 \mathrm{~cm}$ widths, respectively. The center of the target was at a height of $120 \mathrm{~cm}$. Participants had to stand $2 \mathrm{~m}$ from the target and to perform two blocks of 20 trials. A 
Calábria-Lopes, M.; Greco, P. J. \& Pérez-Morales, J. C. (2019). Teaching Games for Understanding in basketball camp: the impact on process and product performance. RICYDE. Revista internacional de ciencias del deporte. 56(15), 209-224.

https://doi.org/10.5232/ricyde2019.05606

Sony digital video camera (model DCR-TRV900E) was used to film the target. When the participant overpassed the distance line, did not throw with both hands or did not catch the ball without bouncing, the pass attempt was not counted and the time continued to run until the participant had completed 20 valid trials. To prevent excessive physical stress, all blocks were separated by an interval of at least two minutes. Participants were allowed to perform two practice trials for shooting and passing in both test phases. Only the best block of each test phase was used for analysis to reduce the intra-individual variance.

(b) Product performance of basketball shooting and passing performance in game conditions Participants played a modified three vs. three game on a basketball half-court during eight minutes. The Skill Execution Index (SEI) of the Game Performance Assessment Instrument GPAI (Mitchell et al., 2006) was used to assess the performance of basketball passing and shooting skills in game conditions. The rater evaluated participants action as either "efficient" or "inefficient" according to the criteria presented in Table 3. The game was recorded using a Sony digital video camera (model DCR-TRV900E) and was further analyzed by two independent raters. Reliability of the data was measured through the Cohen's Kappa test (Robinson and O'Donoghue, 2007), reaching values between .71 and .87 in the pretest and values between .75 and .87 in the posttest. Hence, the performance indicators were calculated according to the protocol of Mitchell et al. (2006) with the changes proposed by Memmert and Harvey (2008) for each skill. These changes consider the assessment of all raters ( $k=1$ to $n)$ for efficient $\left(a_{e}\right)$ and inefficient actions $\left(a_{i}\right)$ and create values from 0 to 2 for each coder (equation 1). Results above 1.0 indicate success, with more efficient than inefficient actions.

$$
\text { SEI }=2 x \frac{\sum_{k=1}^{n}\left(a_{e}+1\right)}{\sum_{k=1}^{n}\left(a_{e}+a_{i}+2\right)}
$$

(c) Process performance of basketball shooting and passing skills - Participants were asked to throw the ball into the basket without jumping. The same distance of the shooting product performance test was used. In the pass test, participants were required to execute the chest pass with two hands to a teammate in $3 \mathrm{~m}$ apart. In both tests, participants had two attempts and were instructed to use the correct technique without worrying about their actions result. Participants' performance was recorded using a Sony digital video camera (model DCRTRV900E) and was further analyzed by two independent raters. The raters evaluated the movement rules that children fulfilled within two attempts, according to the skill execution description in Table 4 (adapted from Schroeder and Bauer, 2001). In this method the technique is divided in small components and sub-phases and analyzed by video, as recommended in the literature (Carling, Reilly and Willliams, 2009; Lees, 2002). The inter-rater reliability of this evaluation method for each technique test considered the number of movement rules executed in the pretest $\left(\kappa_{\text {pass }}=.72 ; \kappa_{\text {shooting }}=.71\right)$ and posttest $\left(\kappa_{\text {pass }}=.89 ; \kappa_{\text {shooting }}=.75\right)$.

(d) Declarative knowledge - The aim of this analysis was to ensure that participants learned through an explicit process. All participants were asked to fill out the Declarative Knowledge Questionnaire (Masters and Maxwell, 2004), before and after the intervention. This questionnaire regards all the rules, coaching tips, and strategies they felt were important for the execution of the shooting and chest pass skills in basketball. Explicit rules were measured by comparing the number of written rules related to the position and/or movement of the feet, leg, body, arm, and the ball to a list of set instructions (Schroeder and Bauer, 2001). Two independent raters counted the number of explicit rules reported by each participant relating to a motor skill execution (e.g., "I kept my forearm vertical" or "I extended my elbow when I 
Calábria-Lopes, M.; Greco, P. J. \& Pérez-Morales, J. C. (2019). Teaching Games for Understanding in basketball camp: the impact on process and product performance. RICYDE. Revista internacional de ciencias del deporte. 56(15), 209-224.

https://doi.org/10.5232/ricyde2019.05606

shot"). Statements that were irrelevant to technical performance such as "I bounced the ball twice before shooting" were not included. Significant high ICC values were found for both pretest $\left(\kappa_{\text {pass }}=.78 ; \kappa_{\text {shooting }}=.91\right)$ and posttest $\left(\kappa_{\text {pass }}=.83 ; \kappa_{\text {shooting }}=.85\right)$. Means were calculated from the combined scores of both raters.

Table 4: Criteria for Process- and Product-Oriented Assessment of Basketball Shooting and Passing Skills

\begin{tabular}{|c|c|c|}
\hline $\begin{array}{c}\text { Product-oriented assessment } \\
\text { Isolated Skill }\end{array}$ & $\begin{array}{l}\text { Product-oriented assessment } \\
\text { In game conditions }\end{array}$ & Process-oriented assessment \\
\hline Shooting skill & & \\
\hline $\begin{array}{l}\text { (1) Six-point scale: } 5 \text { for a } \\
\text { "clean"' basket (i.e., } \\
\text { "'swish"); } 4 \text { for rim and in; } \\
3 \text { for backboard and in; } 2 \\
\text { for rim and out; } 1 \text { for } \\
\text { backboard and out; and } 0 \\
\text { for a complete miss }\end{array}$ & $\begin{array}{l}\text { (1) Efficient: ball shot on target } \\
\text { (not necessarily scores a } \\
\text { basket) } \\
\text { (2) Inefficient: shot intercepted, } \\
\text { shot out of the target. }\end{array}$ & $\begin{array}{l}\text { (1) Feet shoulder-width apart } \\
\text { pointing toward the basket. } \\
\text { (2) Elbow of shooting arm } \\
\text { under the ball. } \\
\text { (3) Ball is hold only with the } \\
\text { fingertips. } \\
\text { (4) Extend the body fully from } \\
\text { the bottom up toward the } \\
\text { roof } \\
\text { (5) After the ball is released, } \\
\text { snap the wrist toward the } \\
\text { basket - shooting hand is } \\
\text { facing downward. }\end{array}$ \\
\hline $\begin{array}{l}\text { (1) Accuracy: the square where } \\
\text { the ball hit (most part): } 3 \\
\text { points = smallest square; } 2 \\
\text { points = medium square; } 1 \\
\text { point = largest square, and } 0 \\
\text { point = outside of the target. } \\
\text { (2) Speed: time took to } \\
\text { complete } 20 \text { valid passes. }\end{array}$ & $\begin{array}{l}\text { (1) Efficient: ball reaches the } \\
\text { target (teammate). } \\
\text { (2) Inefficient: pass } \\
\text { intercepted, pass out of } \\
\text { play, pass is too far behind } \\
\text { or in front of a teammate }\end{array}$ & $\begin{array}{l}\text { (1) Feet pointing towards the } \\
\text { target. } \\
\text { (2) Step towards the target. } \\
\text { (3) Hold the ball with both } \\
\text { hands at chest level. } \\
\text { (4) Extend the arms forwards. } \\
\text { (5) After the ball is released, } \\
\text { both hands are pointing } \\
\text { outward and the thumbs } \\
\text { toward the ground. }\end{array}$ \\
\hline
\end{tabular}

\section{Data analysis}

The software SPPS 22.0 was used to analyze and process the data. The data was first checked for outliers (i.e., two standard deviations or more from the mean value) and normality (i.e., Shapiro-Wilk test). Variables are presented as mean (standard deviation). Spearman's Rho correlations were conducted to verify the relationship between process and product scores for shooting and passing skills and the declarative knowledge of both skills. Paired $t$-tests or Wilcoxon tests were used to compare pre and posttest scores for each dependent variable. Effect sizes were calculated using Cohen's $d$ or $r$, according to the formula $r=z / \sqrt{ } \mathrm{N}$. Statistical significance was set at $p<.05$ for all analyses.

\section{Results}

\section{Correlations between dependent variables}

Table 5 presents the correlations between process, product, and declarative knowledge scores for shooting and passing skills. Only the values of the pretest were used and the scores of points and time of product performance of the passing skill in isolation were $z$ transformed. No significant correlations were found for any of the variables. 
Calábria-Lopes, M.; Greco, P. J. \& Pérez-Morales, J. C. (2019). Teaching Games for Understanding in basketball camp: the impact on process and product performance. RICYDE. Revista internacional de ciencias del deporte. 56(15), 209-224.

https://doi.org/10.5232/ricyde2019.05606

Table 5: Correlations between Process, Product, and Declarative Knowledge Scores

\begin{tabular}{lcccc}
\hline \multicolumn{1}{c}{ Skill } & $\begin{array}{c}\text { Product - } \\
\text { isolated }\end{array}$ & $\begin{array}{c}\text { Product - } \\
\text { game }\end{array}$ & Process & $\begin{array}{c}\text { Declarative } \\
\text { Knowledge }\end{array}$ \\
\hline Shooting skill & 1 & .312 & .046 & .036 \\
$\begin{array}{l}\text { Product - isolated } \\
\text { Product - game }\end{array}$ & & 1 & .032 & .001 \\
Process & & & 1 & .074 \\
Declarative Knowledge & & & & 1 \\
Passing skill & 1 & .326 & .099 & .332 \\
& & 1 & .070 & .323 \\
Product - isolated & & & .030 \\
Product - game & & & & 1 \\
Process & & & & \\
Declarative Knowledge & & & & \\
\hline a & & & & \\
\hline
\end{tabular}

${ }^{\mathrm{a} Z}$ score for pass accuracy and speed

\section{Effects of TGfU approach in a basketball camp setting on process and product performance}

The descriptive statistics and pairwise comparisons for the dependent variables are presented in Table 6.

Table 6: Means, Standard Deviations, Effect Sizes, and Significant Differences for Dependent Variables according to Test Phase

\begin{tabular}{|c|c|c|c|c|c|c|}
\hline \multirow{2}{*}{$\begin{array}{l}\text { Dependent } \\
\text { variables }\end{array}$} & \multicolumn{2}{|c|}{ Pretest } & \multicolumn{2}{|c|}{ Posttest } & \multirow{2}{*}{ Effect size } & \multirow{2}{*}{$p$} \\
\hline & Mean & SD & Mean & SD & & \\
\hline \multicolumn{7}{|c|}{ Product performance - isolated skills } \\
\hline Shooting & 26.28 & 4.31 & 27.78 & 5.66 & .37 & .132 \\
\hline Pass (time) & 21.82 & 4.62 & 22.54 & 4.80 & .14 & .546 \\
\hline Pass (points) & 51.83 & 4.94 & 49.22 & 6.92 & .43 & .084 \\
\hline \multicolumn{7}{|c|}{ Product performance - in game conditions } \\
\hline Shooting game & $.96^{\circ}$ & .23 & 1.16 & .26 & .53 & .036 \\
\hline Pass game ${ }^{\mathrm{a}}$ & 1.41 & .34 & 1.40 & .25 & .06 & .727 \\
\hline \multicolumn{7}{|c|}{ Process performance } \\
\hline Shooting ${ }^{\mathrm{a}}$ & 3.00 & .96 & 3.31 & .61 & .29 & .079 \\
\hline Pass $^{\mathrm{a}}$ & 2.04 & .64 & 2.38 & .71 & .34 & .043 \\
\hline \multicolumn{7}{|c|}{ Declarative Knowledge } \\
\hline Shooting $^{\mathrm{a}}$ & .19 & .34 & 1.53 & .99 & .55 & .001 \\
\hline Pass $^{\mathrm{a}}$ & .86 & .51 & 1.78 & .79 & .53 & .001 \\
\hline
\end{tabular}

For product performance of isolated skills, there were no significant differences from pretest to posttest for shooting $\left(t_{17}=-1.58, p=.132, d=.37\right)$, passing time $\left(t_{17}=-.62, p=.546, d=.14\right)$, and passing points $\left(t_{17}=1.84, p=.084, d=.43\right)$. However, significant differences for shooting skill in games conditions $\left(t_{17}=-2.28, p=.036, d=.53\right)$ indicated improvements in this skill after intervention, but not for pass skill $(\mathrm{Z}=-.35, p=.727, r=.06)$. Regarding the process performance, results showed a significant improvement from pretest to posttest in passing skill $(\mathrm{Z}=-2.02, p=.043, r=.34)$ and no significant changes in the shooting skill $(\mathrm{Z}=-1.76, p=$ $.079, r=.29)$.

\section{Declarative Knowledge}

Results showed a significant difference between pretest and posttest for declarative knowledge for shooting $(\mathrm{Z}=-3.32, p=.001, r=.55)$ and passing skills $(\mathrm{Z}=-3.20, p=.001, r=.53)$, that is, participants increased the number of movement rules in both skills. 
Calábria-Lopes, M.; Greco, P. J. \& Pérez-Morales, J. C. (2019). Teaching Games for Understanding in basketball camp: the impact on process and product performance. RICYDE. Revista internacional de ciencias del deporte. 56(15), 209-224.

https://doi.org/10.5232/ricyde2019.05606

\section{Discussion}

The first purpose of the current study was to verify the relationship between process and product performance of basketball shooting and passing skills in children. In contrast to previous studies (Haubenstricker and Branta, 1997; Logan, Barnett, Goodway and Stodden, 2017; Roberton and Konczak, 2001; Stodden et al., 2006b; Stodden et al., 2006a;), our results showed no significant correlations between process and product performances for shooting and passing skills in basketball novices. Although these studies were performed with children, they compared both the product and process performance of fundamental motor skills (e.g. throw - Logan et al., 2017; Roberton and Konczak, 2001; Stodden et al., 2006a, Stodden et al., 2006b; standing long jump - Haubenstricker and Branta, 1997; Logan et al., 2017; hop - Logan et al., 2017) and not a sport-specific skill as in this research. These differences between studies methods hinders the comparison between results. The small sample size used in the current study may have also contributed to the lack of relationship between the variables.

The second aim of this work was to examine the effects of TGfU approach in a basketball camp over five consecutive days and with five hours per day of training on the acquistion of shooting and passing basketball skills in children. The product-oriented assessment of shooting and passing isolated skills showed no significant improvement from pretest to posttest. Although the TGfU model presents a stage in which technical skills are practiced in isolation, this is done from within a context of the game (Kirk and MacPhail, 2002). This requires learners to develop problem-solving skills and understand the purpose of practicing either a technical skill (i.e. pass, dribbling and shooting in basketball), or a strategic tactical maneuver (i.e. set a pick for a teammate) (Hopper and Kruisselbrink, 2002). Therefore, we should not expect improvement in isolated skills. On the other hand, if we consider the TGfU as an explicit learning model (Raab, 2007), this study results are not in accordance with motor learning research. In previous studies (Lam et al., 2009; Masters, 1992; Schlapkohl, Hohmann and Raab, 2012), improvements were observed in performance of a single sport technical skill (eg., shooting in basketball, forehand in table tennis, golf putting) learned through step-by-step explicit method. However, in most of these works (see Schlapkohl et al., 2012 for exception), the subjects were adults and the technical and tactical aspects were treated separately to reduce the complexity of the learning situation. In the present study, the basketball shooting skill was investigated in children following an integrated training intervention (technical and tactical), as proposed by the TGfU approach.

In addition, regarding the overall skill execution in game-like situations, significant differences and a high effect size were observed at the posttest compared to the pretest assessment for the shooting skill, but not for the passing skill. This suggested a significant improvement in the shooting skill in game context, which was also observed in previous studies with the TGfU approach in other team sports (Hockey - Nathan, 2015; Soccer - Harvey et al., 2010; Pizarro et al., 2017). According to Barakat et al. (2011), the acquisition of a motor skill generally relies on several phases of learning, including a fast early learning stage and a slow later stage. This could explain the absence of significant improvement of the passing skill during the game, given that participants showed a high initial score for this action. It is possible that the differences in performance between passing and shooting skills were due to different enjoyment in pass and shooting actions in basketball - shooting is one of the favorite actions of young basketball players (Arias, 2012). However, this study did not assess participants enjoyment or motivation during the learning phase and future studies should test this alternative explanation.

Conversely, in terms of process performance, a significant improvement - medium effect size - was advocated for passing, but not for shooting. According to Logan et al. (2017), limitations of qualitative assessments to adequately capture certain aspects of coordination patterns may be reflective of an increase of a process-oriented assessment. It is important to highlight that 
Calábria-Lopes, M.; Greco, P. J. \& Pérez-Morales, J. C. (2019). Teaching Games for Understanding in basketball camp: the impact on process and product performance. RICYDE. Revista internacional de ciencias del deporte. 56(15), 209-224.

this was the first study to analyze the effect of a game approach intervention on process performance of sport skills and allow to show evidence of the effects of TGfU for shooting and passing skills acquisition by novices in basketball.

Another novelty on this study is the intervention with TGfU approach in a format of sport camp, which lasted much longer than other standard testing (22.5 hours). One can argue that five hours a day is too much for the participants of the present study, who are between 10 and 12 years old and it could be the reason for no significant differences in some variables. However, many sport camps encourage children to practice only one sport over one week or more, with a general day program (5-6 hours day) or overnight program (Smith et al., 2006). Furthermore, knowledge regarding health and technical outcomes of short time, game-centered training volume in children is limited. We found only one research (Fittipaldi-Wert, Brock, Hastie, Arnold, and Guarino, 2009) with a design of a week-long sports camp, but participants were students with visual impairments and they practice various sports.

The analysis of declarative knowledge indicated that the participants reported significantly more movement rules in shooting and passing skills in the posttest compared to pretest. These results replicate previous work that used explicit instruction to teach sport skills (see Masters, 2013: for a review). The findings for declarative knowledge may be related to the fact that declarative learning can be very fast and may take place even after a single event, while procedural learning may take longer (Fitts, 1964).

It is important to highlight that, similar to previous studies with TGfU intervention (MoralesBelando and Arias-Estero, 2017; Harvey et al., 2010; Pizarro et al., 2017), the results of the current study should be interpreted carefully due to the lack of a control group. Future research should include a control group to give more power to the results and discussion of the study.

Another problem that should be noted is the subjective measure of the process-performance, which was done through the observation of two independent raters and not through kinematics parameters. Notwithstanding, results from work of Lam et al. (2009) indicated a strong association between number of subjective and objective movement components.

\section{Conclusions}

This study found no correlation between process- and product-oriented assessments of basketball shooting and passing skills. However, it seems that the TGfU approach through an intervention in format of a basketball camp, over five consecutive days, has a positive and significant effect on process performance of passing and product performance of shooting skills in game context.

Despite the limitations of the present study, we believe that our findings provide further knowledge on process- and product-oriented assessments of sport-specific skills after a gamecentered intervention in a sport camp. Continued research is required to determine how combined training (technical and tactical) through game-centered approaches, like TGfU, can improve motor learning of sports skills regarding process and product performance in short and wide intervention time. We recommend the use of both process- and product-oriented assessments to evaluate the sport-specific skill execution, to provide a more accurate evaluation of technical performance and a comprehensive assessment of sport skills. 
Calábria-Lopes, M.; Greco, P. J. \& Pérez-Morales, J. C. (2019). Teaching Games for Understanding in basketball camp: the impact on process and product performance. RICYDE. Revista internacional de ciencias del deporte. 56(15), 209-224.

\section{References}

Anderson-Butcher, D.; Iachini, A.; Riley, A.; Wade-Mdivanian, R.; Davis, J., \& Amorose, A. (2013). Exploring the impact of a summer sport-based youth development program. Evaluation and Program Planning, 37, 64-69.

https://doi.org/10.1016/j.evalprogplan.2013.01.002

Araujo, R.; Mesquita, I.; Hastie, P., \& Pereira, C. (2015). Students' game performance improvements during a hybrid sport education-step-game-approach volleyball unit. European Physical Education Review, 22(2), 185-200. https://doi.org/10.1177/1356336X15597927

Arias, J. L.; Argudo, F. M., \& Alonso, J. I. (2012). Effect of ball mass on dribble, pass, and pass reception in 9-11-year-old boys' basketball. Research Quartely for Exercise and Sport, 83(3), 407-412.

https://doi.org/10.1080/02701367.2012.10599875

Barakat, M.; Doyon, J.; Debas, K.; Vandewalle, G.; Morin, A.; Poirier, G., . . . Carrier, J. (2011). Fast and slow spindle involvement in the consolidation of a new motor sequence. Behavioural Brain Research, 217(1), 117-121.

https;//doi.org/10.1016/j.bbr.2010.10.019

Bialeschki, M.; Henderson, K., \& James, P. (2007). Camp experiences and developmental outcomes for youth. Child and Adolescent Psychiatric Clinics of North America, 16, 769788.

https://doi.org/10.1016/j.chc.2007.05.011

Capio, C. M.; Sit, C. H. P., \& Abernethy, B. (2011). Fundamental movement skills testing in children with cerebral palsy. Disability \& Rehabilitation, 33, 2519-2528. https://doi.org/10.3109/09638288.2011.577502

Carling, C.; Reilly, T., \& Williams, A. M. (2009). Performance assessment for field sports. New York, NY: Routledge.

Corrêa, U. C.; Vilar, L.; Davids, K., \& Renshaw, I. (2014). Interpersonal angular relations between players constrain decision-making on the passing velocity in futsal. Advances in Physical Education, 4(2), 93-101. https://doi.org/10.4236/ape.2014.42013

Crespo, M.; Reid, M., \& Miley, D. (2004). Tennis: Applied examples of a game-based teaching approach. Strategies: A Journal of Physical Education and Sport Educators, 17(4), 27-30.

https://doi.org/10.1080/08924562.2004.10591100

De Knop, P. (1996). European trends in youth sport: A report from 11 European countries. European Journal of Physical Education, 1(1-2), 35-45. http://doi.org/10.1080/1740898960010104

Donnelly, F. C.; Mueller, S. S., \& Gallahue, D. L. (2017). Developmental physical education for all children: theory into practice (5th ed.). Champaign, IL: Human Kinetics.

Fittipaldi-Wert, J., Brock, S.; Hastie, P.; Arnold, J., \& Guarino, A. (2009). Effects of a sport education curriculum model on the experiences of students with visual impairments. Palaestra 24(3), 6-10.

Fitts, P. M. (1964). Perceptual-motor skill learning. In A. W. Melton (Ed.), Categories of human learning (pp. 243-285). New York, NY: Academic Press.

French, K.; Werner, P. H.; Rink, J.; Taylor, K., \& Hussey, K. (1996). The effects of a 3week unit of tactical, skill, or combined tactical and skill instruction on badminton performance of ninth-grade students. Journal of Teaching in Physical Education, 15(4), 418-438.

https://doi.org/10.1123/jtpe.15.4.418 
Calábria-Lopes, M.; Greco, P. J. \& Pérez-Morales, J. C. (2019). Teaching Games for Understanding in basketball camp: the impact on process and product performance. RICYDE. Revista internacional de ciencias del deporte. 56(15), 209-224.

https://doi.org/10.5232/ricyde2019.05606

French, K.; Werner, P. H.; Taylor, K.; Hussey, K., \& Jones, K. (1996). The effects of a 6week unit of tactical, skill, or combined tactical and skill instruction on badminton performance of ninth-grade students. Journal of Teaching in Physical Education, 15(4), 439-463.

https://doi.org/10.1123/jtpe.15.4.439

Griffin, L., \& Patton, K. (2005). Two decades of teaching games for understanding: looking at the past, present, and future. In L. Griffin \& J. Butler (Eds.), Teaching games for understanding: theory, research, and practice (pp. 1-18). Champaign, IL: Human Kinetics.

Gutierrez, D. (2016). Game-centered approaches: Different perspectives, same goalsworking together for learning. Research Quarterly for Exercise and Sport, 87(Sup1), 2324. https://doi.org/10.1080/02701367.2016.1213610

Harvey, S., Cushion, C. J., Wegis, H. M., \& Massa-Gonzalez, A. N. (2010). Teaching games for understanding in American high-school soccer: a quantitative data analysis using the game performance assessment instrument. Physical Education and Sport Pedagogy, 15(1), 29-54. https://doi.org/10.1080/17408980902729354

Hopper, T., \& Kruisselbrink, D. (2002). Teaching Games for Understanding: What does it look like and how does it influence student skill learning and game performance? AVANTE, 1-29.

Hulteen, R. M.; Lander, N. J.; Morgan, P. J.; Barnett, L. M.; Robertson, S. J., \& Lubans, D. R. (2015). Validity and Reliability of Field-Based Measures for Assessing Movement Skill Competency in Lifelong Physical Activities: A Systematic Review. Sports Medicine, 45(10), 1443-1454.

https://doi.org/10.1007/s40279-015-0357-0

Kirk, D., \& MacPhail, A. (2002). Teaching games for understanding and situated learning: rethinking the Bunker-Thorpe model. Journal of Teaching in Physical Education, 21(2), 177-192. https://doi.org/10.1123/jtpe.21.2.177

Koekoek, J., \& Knoppers, A. (2015). The role of perceptions of friendships and peers in learning skills in physical education. Physical Education and Sport Pedagogy, 20(3), 231-249.

https://doi.org/10.1080/17408989.2013.837432

Kröger, C., \& Roth, K. (2005). Ballschule - ein ABC für Spielanfänger. Schorndorf: Hofmann.

Lam, W. K.; Maxwell, J. P., \& Masters, R. S. W. (2009). Analogy versus explicit learning of a modified basketball shooting task: Performance and kinematic outcomes. Journal of Sports Sciences, 27(2), 179-191. https://doi.org/10.1080/02640410802448764

Lees, A. (2002). Technique analysis in sports: a critical review. Journal of Sports Sciences, 20(10), 813-828. https://doi.org/10.1080/026404102320675657

LeMar, B., \& Deutsch, J. (2015). How to run a successful and educational basketball camp. International Journal of Human Sciences, 12(1), 1182-1188. https://doi.org/10.14687/ijhs.v12i1.3241

Logan, S. W.; Barnett, L. M.; Goodway, J. D., \& Stodden, D. F. (2017). Comparison of performance on process- and product-oriented assessments of fundamental motor skills across childhood. Journal of Sports Sciences, 35(7), 634-641.

https://doi.org/10.1080/02640414.2016.1183803 
Calábria-Lopes, M.; Greco, P. J. \& Pérez-Morales, J. C. (2019). Teaching Games for Understanding in basketball camp: the impact on process and product performance. RICYDE. Revista internacional de ciencias del deporte. 56(15), 209-224.

https://doi.org/10.5232/ricyde2019.05606

Logan, S. W.; Robinson, L. E., \& Getchell, N. (2011). The comparison of performances of preschool children on two motor assessments. Perceptual and Motor Skills, 113(3), 715723.

htpps://doi.org/10.2466/03.06.25.PMS.113.6.715-723

Masters, R. S. (1992). Knowledge, knerves and know-how: The role of explicit versus implicit knowledge in the breakdown of a complex motor skill under pressure. Britisch Journal of Psychology, 83, 343-358. https://doi.org/10.1111/j.2044-8295.1992.tb02446.x

Masters, R. S. (2013). Practicing implicit motor learning. In D. Farrow, J. Baker, \& C. MacMahon (Eds.), Developing sport expertise: researchers and coaches put theory into practice (pp. 154-174). London, UK: Routledge.

Masters, R. S., \& Maxwell, J. P. (2004). Implicit motor learning, reinvestment and movement disruption: What you don't know won't hurt you? In A. M. Williams \& N. J. Hodges (Eds.), Skill acquisition in Sport: Research, theory and practice (pp. 207-228). London, UK: Routledge.

Masters, R. S.; Poolton, J. M., \& Maxwell, J. P. (2008). Stable implicit motor processes despite aerobic locomotor fatigue. Consciousness and Cognition, 17(1), 335-338. https://doi.org/10.1016/j.concog.2007.03.009

Maxwell, J. P.; Capio, C. M., \& Masters, R. S. (2017). Interaction between motor ability and skill learning in children: Application of implicit and explicit approaches. European Journal Sport Science, 17(4), 407-416. https://doi.org/10.1080/17461391.2016.1268211

Maxwell, J. P.; Masters, R. S., \& Eves, F. F. (2003). The role of working memory in motor learning and performance. Consciousness and Cognition, 12(3), 376-402.

Memmert, D.; Almond, L.; Bunker, D.; Butler, J.; Fasold, F.; Griffin, L., . . . Furley, P. (2015). Top 10 Research Questions Related to Teaching Games for Understanding. Research Quartely for Exercise and Sport, 86(4), 347-359. https://doi.org/10.1080/02701367.2015.1087294

Memmert, D., \& Harvey, S. (2008). The game performance assessment instrument (GPAI): Some concerns and solutions for further development. Journal of Teaching in Physical Education, 27(2), 220-240.

https://doi.org/10.1123/jtpe.27.2.220

Mesquita, I.; Farias, C., and Hastie P. (2012). The impact of a hybrid Sport EducationInvasion Games Competence Model soccer unit on students' decision making, skill execution and overall game performance. European Physical Education Review, 18(2), 205-219. https://doi.org/10.1177/1356336X12440027

Metzler, M. W. (2011). Instructional models for physical education (3rd ed.). New York, NY: Routledge.

Mitchell, S. A.; Oslin, J. L., \& Griffin, L. L. (2006). Teaching sports concepts and skills: A tactical games approach (2nd ed.). Champaign: Human Kinetics.

Morales-Belando, M. T., \& Arias-Estero, J. L. (2017). Influence of teaching games for understanding on game performance, knowledge, and variables related to adherence in youth sailing. Journal of Teaching in Physical Education, 36(2), 209-219. https://doi.org/10.1123/jtpe.2016-0024

Nathan, S. (2015). Coaching school hockey in Malaysia: A exploratory analysis and effect of improvised TGfU pedagogical model on small sided game play. Journal of Physical Education and Sport, 15(4), 712-723.

https://doi.org/10.7752/jpes.2015.04109 
Calábria-Lopes, M.; Greco, P. J. \& Pérez-Morales, J. C. (2019). Teaching Games for Understanding in basketball camp: the impact on process and product performance. RICYDE. Revista internacional de ciencias del deporte. 56(15), 209-224.

https://doi.org/10.5232/ricyde2019.05606

Nicholls, R.; Fleisig, G.; Elliott, B.; Lyman, S., \& Osinski, E. (2003). Accuracy of qualitative analysis for assessment of skilled baseball pitching technique. Sports Biomechanics, 2(2), 213-226.

https://doi.org/10.1080/14763140308522819

Pill, S. (2006). Teaching games for understanding. Sports Coach, 29, 1-4.

Pizarro, A. P.; Dominguez, A. M.; Serrano, J. S.; Garcia-Gonzalez, L., \& Alvarez, F. V. (2017). The effects of a comprehensive teaching program on dribbling and passing decision-making and execution skills of young footballers. Kinesiology, 49(1), 74-83.

Poolton, J. M.; Masters, R. S., \& Maxwell, J. P. (2007). Passing thoughts on the evolutionary stability of implicit motor behaviour: performance retention under physiological fatigue. Consciousness and Cognition, 16(2), 456-468.

https://doi.org/10.1016/j.concog.2006.06.008

Raab, M. (2007). Think SMART, not hard - a review of teaching decisions making in sport from an ecological rationality perspective. Physical Education and Sport Pedagogy, 12(1), 1-22.

https://doi.org/10.1080/17408980601060184

Riley, A., \& Anderson-Butcher, D. (2012). Participation in a summer sport-based youth development program for disadvantaged youth: Getting the parent perspective. Children and Youth Services Review, 34, 1367-1377.

https://doi.org/10.1016/j. childyouth.2012.03.008

Rink, J.; French, K., \& Tjeerdsma, B. (1996). Foundations for learning and instruction of sport and games. Journal of Teaching in Physical Education, 15(4), 399-417. https://doi.org/10.1123/jtpe.15.4.399

Roberton, M. A., \& Konczak, J. (2001). Predicting children's overarm throw ball velocities from their developmental levels in throwing. Research Quartely for Exercise and Sport, 72(2), 91-103.

https://doi.org/10.1080/02701367.2001.10608939

Robinson, G., \& O'Donoghue, P. (2007). A weighted kappa statistic for reliability testing in performance analysis of sport. International Journal of Performance Analysis in Sport, 7(1), 12-19.

https://doi.org/10.1080/24748668.2007.11868383

Rudd, J., Butson, M. L., Barnett, L., Farrow, D., Berry, J., Borkoles, E., \& Polman, R. (2016). A holistic measurement model of movement competency in children. Journal of Sports Sciences, 34(5), 477-485.

https://doi.org/10.1080/02640414.2015.1061202

Salazar, C. M.; Lozano, R. J.; Sánchez, A. I. A.; Vargas, C. S. P.; Ceballos, A. C. A., \& Murúa, J. A. H. (2016). Percepción del beneficio de los deportes y actividades recreativas en habilidades para la vida en niños y adolescentes de Ciudad Juárez, México. Sportis, 2(3), 356-378.

Schlapkohl, N., Hohmann, T., \& Raab, M. (2012). Effects of instructions on performance outcome and movement patterns for novices and experts in table tennis. International Journal of Sport Psychology, 6, 522-541.

Schroeder, J., \& Bauer, C. (2001). Basketball: trainieren uns spielen [Basketball: training and play]. Reinbek: Rowohlt.

Smith, A.; Ullrich-French, S.; Walker II, E., \& Hurley, K. (2006). Peer relationship profiles and motivation in youth sport. Journal of Sport \& Exercise Psychology, 28, 362-382. https://doi.org/10.1123/jsep.28.3.362

Showalter, D. (2007). Coaching youth basketball. Champaign: Human Kinetics. 
Calábria-Lopes, M.; Greco, P. J. \& Pérez-Morales, J. C. (2019). Teaching Games for Understanding in basketball camp: the impact on process and product performance. RICYDE. Revista internacional de ciencias del deporte. 56(15), 209-224.

https://doi.org/10.5232/ricyde2019.05606

Stodden, D. F., Goodway, J. D., Langendorfer, S. J., Roberton, M. A., Rudisill, M. E., Garcia, C., \& Garcia, L. E. (2008). A developmental perspective on the role of motor skill competence in physical activity: An emergent relationship. Quest, 60, 290-306. https://doi.org/10.1080/00336297.2008.10483582

Stodden, D. F., Langendorfer, S. J., Fleisig, G. S., \& Andrews, J. R. (2006a). Kinematic constraints associated with the acquisition of overarm throwing part I: step and trunk actions. Research Quartely for Exercise and Sport, 77(4), 417-427. https://doi.org/10.1080/02701367.2006.10599377

Stodden, D. F., Langendorfer, S. J., Fleisig, G. S., \& Andrews, J. R. (2006b). Kinematic constraints associated with the acquisition of overarm throwing part II: upper extremity actions. Research Quartely for Exercise and Sport, 77(4), 428-436. https://doi.org/10.1080/02701367.2006.10599378

Stolz, S., \& Pill, S. (2014). Teaching games and sport for understanding: Exploring and reconsidering its relevance in physical education. European Physical Education Review, 20(1), 36-71. https://doi.org/10.1177/1356336X13496001

Strean, W., \& Holt, N. (2000). Players', coaches', and parents' perceptions of fun in youth sport. AVANTE, 6, 84-89.

Thurber, C.; Scanlin, M.; Scheuler, L., \& Henderson, K. (2007). Youth development outcomes of the camp experience:evidence for multidimensional growth. Journal of Youth and Adolescence, 36(3), 241-254.

https://doi.org/10.1007/s10964-006-9142-6

Turner, A. P., \& Martinek, T. J. (1999). An investigation into teaching games for understanding: effects on skill, knowledge, and game play. Research Quartely for Exercise and Sport, 70(3), 286-296. https://doi.org/10.1080/02701367.1999.10608047

Wahl-Alexander, Z., \& Morehead, C. A. (2017). Comparing campers 'physical activity levels betweeen Sport Education and traditional instruction in a residential summer camp. Journal of Physical Activity and Health, 14(9), 665-670. https://doi.org/10.1123/jpah.2017-0039

Zwicker, J. G.; Rehal, H.; Sodhi, S.; Karkling, M.; Paul, A.; Hilliard, M.; Jarus, T. (2015). Effectiveness of a summer camp intervention for children with developmental coordination disorder. Physical \& Occupational Therapy in Pediatrics, 35(2), 163-177. https://doi.org/ 10.3109/01942638.2014.957431 